\title{
Effect of lactic acid on the meat quality properties and the taste of pork Serratus ventralis muscle
}

\author{
Alicia Grajales-Lagunes ${ }^{1 *}$, Cecilia Rivera-Bautista ${ }^{1}$, Miguel Ruiz-Cabrera ${ }^{1}$, Raúl González-García ${ }^{1}$, Jorge \\ Ramírez-Télles ${ }^{1}$ and Miguel Abud-Archila ${ }^{2}$
}

\begin{abstract}
${ }^{1}$ Facultad de Ciencias Químicas, Universidad Autónoma de San Luis Potosí, Av. Dr. Manuel Nava \#6, Zona Universitaria, San Luis Potosí, S.L.P. México. C.P. 78210, ²División de Estudios de Posgrado e Investigación, Instituto Tecnológico de

Tuxtla Gutiérrez Chiapas, Carretera Panamericana km 1080. C.P. 29050.

e-mail: *grajales@uaslp.mx
\end{abstract}

\begin{abstract}
In this work was evaluated the effect of lactic acid treatment method in pork Serratus ventralis muscle on meat quality parameters $\mathrm{pH}$, color, weight loss, cooking loss, hardness, and taste. The treatment was performed by immersing the sample in lactic acid solutions at two concentrations $\left(1\right.$ and $\left.3 \% \vee v^{-1}\right)$ for 1 and $3 \mathrm{~min}$., immediately the samples were stored at $4{ }^{\circ} \mathrm{C}$ during 7 days. The taste was evaluated employing trained and untrained judges. Only hardness, weight loss and cooking loss, were affected by lactic acid concentration $(p<0.05)$. The perception of lactic acid taste to trained judges was higher in samples of major concentration and immersion time. To untrained judges the sample treated with $3 \%$ lactic acid for 1 minute, had the best acceptation. Both judges reported that the taste of meat was delicious. Therefore, lactic acid treatment may be an alternative to extend pork shelf life.
\end{abstract}

Key words: meat quality, taste, lactic acid, pork

\section{Introduction}

Meat, due to its chemical composition of $75 \%$ water, $19 \%$ proteins, and $6 \%$ non-protein substances (Lawrie 1998) is a nutritive substrate and a very adequate one for development of pathogenic and nonpathogenic microorganisms, once the animal has been slaughtered. In order to avoid microbial growth and to extend the shelf life of meat, different methods have been proposed in literature such as steaming, hot water washing and vacuum packing (Dorsa et al. 1996, Kozempel et al. 2003), as well as the use of acetic and lactic acid solutions. Lactic acid has been frequently employed to decontaminate carcasses of different species, and a significant drop in the microbial load has been observed for pathogenic and non-pathogenic microorganisms (Van Netten et al. 1998, Castillo et al. 2001, Ikeda et al. 2003, JimenezVillareal et al. 2003ab, Ozdemir et al. 2006). The lactic acid effect could be associated to changes in the acid/base equilibrium, the donation of protons and the interference of cell energy production. If intracellular $\mathrm{pH}$ is higher than acid dissociation constant ( $\mathrm{pKa}$ ), the acid may disassociate by releasing a proton, and by this way to acidify the cytoplasm of the microorganism (Booth 1985). The antibacterial effect of lactic acid varies depending on the concentration, temperature and the method of application (Tamblyn and Conner 1997). The effect of lactic acid on meat quality and sensory properties has been studied in different species such as cattle, chicken, buffalo and pig (Jimenez-Villareal et al. 2003ab, Kotula and Thelappurath 1994, Pipek et al. 2005, Deumier 2004, Surve et al. 1991, Van Netten et al.1995, Jensen et al. 2003). The parameter most studied is color and it has been observed that the modifications that occur depend mainly of the lactic acid concentration, and method applied. For example, color of chicken skin

Manuscript received April 2011 


\section{AGRICULTURAL AND FOOD SCIENCE}

A. Grajales-Lagunes et al. (2012) 21: 171-181

was modified from yellow to green after immersion in lactic acid solution (Kotula and Thelappurath 1994, Deumier 2004). For instance in beef cuts treated in lactic acid solution an increase in $L^{*}$ value (paleness) and decrease in $a^{*}$ value (redness) was measured whereas in buffalo steaks treated with $3 \%$ solutions of lactic acid the color change was no significant (Jimenez-Villareal et al. 2003ab, Kotula and Thelappurath 1994). In pork unacceptable sensory properties, including color, were obtained after application of hot lactic acid solutions $\left(55^{\circ} \mathrm{C}\right)$ using concentrations of 2 and $5 \%$ for 2 minutes (Van Netten et al.1995). In this context, lactic acid solutions have been usually used in our laboratory to decontaminate the nape, which is widely used to make "Tacos al pastor" (shepherd style) in Mexico. It is important to note that the nape is one of the most contaminated parts of pork carcass (unpublished data). Therefore, the aim of this work was to assess the effect of lactic acid treatment method in pork Serratus ventralis muscle on meat quality parameters $\mathrm{pH}$, change of color, weight loss, cooking loss, hardness, and taste.

\section{Materials and methods}

\section{Sample preparation}

The Serratus ventralis muscle was removed at 24 hours post-mortem, from 28 female pigs, Temisca breed (50\% Landrace and 50\% Duroc). Fourteen muscles were used to evaluate meat quality parameters, and another 14 muscles were used for sensory analysis. Each muscle was divided in five parts of $5 \times 5 \times 2 \mathrm{~cm}$; one part was used as control, another to evaluate $\mathrm{pH}$ and color, two parts were used for texture evaluation, and the last one to assess weight and cooking loss. For sensory evaluation, one part was used as control, and the other four parts were treated with lactic acid solutions, as described below.

\section{Lactic acid treatment}

Commercial lactic acid ( $85 \%{ }^{\circledR}$ MANE de México) was used to prepare the solutions for decontaminating the meat. Lactic acid treatments were done based on randomized factorial design of two factors (Lactic acid concentration and immersion time) with two levels, 1 and $3 \%\left(v^{-1}\right)$, and 1 and 3 minutes, respectively and 3 central points ( $2 \%$ and 2 minutes), one replicate for each experimental condition was used. A total of 14 runs were conducted (Table 1 ). The factors and levels employed were selected of preliminary experiments for the decontamination of pork samples. Each experimental run was done at room temperature $\left(20 \pm 2{ }^{\circ} \mathrm{C}\right)$. Following the treatment, each sample was vacuum packed, and stored at $4{ }^{\circ} \mathrm{C}$ for 7 days.

Table 1. Experimental conditions for acid lactic treatments.

\begin{tabular}{ccccc}
\hline Experiment no & Run order & Lactic acid concentration $\%$ & Time min & Replicate \\
\hline 1 & 5 & 1 & 1 & -1 \\
2 & 10 & 3 & 1 & -1 \\
3 & 12 & 1 & 3 & -1 \\
4 & 3 & 3 & 3 & -1 \\
5 & 7 & 2 & 2 & -1 \\
6 & 2 & 2 & 2 & -1 \\
7 & 14 & 2 & 2 & -1 \\
8 & 8 & 1 & 1 & 1 \\
9 & 9 & 3 & 1 & 1 \\
10 & 6 & 1 & 3 & 1 \\
11 & 1 & 3 & 3 & 1 \\
12 & 4 & 2 & 2 & 1 \\
13 & 13 & 2 & 2 & 1 \\
14 & 11 & 2 & 2 & 1 \\
\hline
\end{tabular}




\section{AGRICULTURAL AND FOOD SCIENCE}

A. Grajales-Lagunes et al. (2012) 21: 171-181

\section{$\mathrm{pH}$ measurement}

The $\mathrm{pH}$ measurements were taken with a pH-meter (Hanna Instruments $\mathrm{HI} 9025$ ) at the core of sample, before ( $\mathrm{pHu})$, at the end of the lactic acid treatment and at the end of the storage stage. It was reported the average of 4 measurements for each sample.

\section{Color measurement}

The samples were read using the $\mathrm{D}_{65}$ primary illuminant through the $\mathrm{CIE} L^{*}, a^{*}$ and $b^{*}$ parameters and employing a spectrophotometer (Konica Minolta CM-2500d) using color software, version 5.2. Six measurements were performed on each sample considering a determined area. The Hue was calculated $\left[\tan ^{-1}\left(b^{*} / a^{*}\right)\right]$ as well as the saturation index $\left(a^{* 2}+b^{* 2}\right)^{1 / 2}$ (Hunt et al. 1991). The total color change $(\Delta E)$ was calculated at 7 days of storage with equation (1) (Rodriguez Hernandez et al. 2005):

$$
\Delta \mathrm{E}=\sqrt{\left(L_{o} *-L^{*}\right)^{2}+\left(a_{o} *-a^{*}\right)^{2}+\left(b_{o} *-b^{*}\right)^{2}}
$$

where: $L_{o} * a_{o} *$ and $b_{o} *$ are the initial color values for the sample before the treatment and $L^{*}, a^{*}$ and $b^{*}$ are the final color values after storage at $4{ }^{\circ} \mathrm{C}$ for 7 days.

\section{Weight changes during processing}

Weight loss in raw and cooked meat was carried out by gravimetric method, using the equation (2):

Weight loss $(\%)=\frac{W_{1}-W_{2}}{W_{1}} X 100$

where $W_{1}$ is the sample weight $(g)$ at the initial time and $W_{2}$ is the sample weight $(g)$ after storage stage.

Concerning the weight loss in cooked meat, $W_{1}$ and $W_{2}$, represents the sample weight before and after cooking, respectively.

\section{Texture measurement}

Two portions of $5 \times 5 \times 2 \mathrm{~cm}$ were cut in $1 \times 1 \times 3 \mathrm{~cm}$ parallelepiped, in order to obtain a total of 10 samples. Then, raw meat hardness was measured in $1 \times 1 \times 3 \mathrm{~cm}$ samples, using compression test in an Instron machine (Model 3365) up to $20 \%$ strain at speed of $50 \mathrm{~mm} \mathrm{~min}^{-1}$. The probe surface was $1 \mathrm{~cm}^{2}$. The compression was perpendicular to the muscle fibers so that samples could deform laterally only in the direction of the muscle fibers (Lepetit and Buffiere 1993). Compression test was carried out at room temperature $\left(20^{\circ} \mathrm{C} \pm 2\right)$ and the average of 10 measurements for each experiment was reported.

\section{Taste evaluation}

Lactic acid treatment of samples for sensory evaluation was conducted using the same experimental design used in quality parameters evaluation. The taste of cooked meat was measured after storage stage. Cooking was carried out on $5 \times 5 \times 2 \mathrm{~cm}$ samples, at $80^{\circ} \mathrm{C}$ for 60 minutes in a water bath. After cooking process, the surface was removed and samples $(1.5 \times 1.5 \times 1.5 \mathrm{~cm})$ were provided to the judges. Before assessing 


\section{AGRICULTURAL AND FOOD SCIENCE}

A. Grajales-Lagunes et al. (2012) 21: 171-181

the samples, the internal temperature of the meat was $65^{\circ} \mathrm{C}$. The taste was evaluated with a panel of 8 trained judges ( 4 men and 4 women, 18-25 years old). Training of the judges was carried out according to the procedure described by Anzaldúa-Morales (1994) during 3 months, assessing the ability of the judges to perceive sweet, salty, bitter and acid tastes. In order to familiarize them with lactic acid taste, judges were provided with non-treated and treated samples, at different concentrations (1, 2, 3 and 4\%) using triangular tests. The ability and acceptance of the 8 judges was validated through a sequential analysis according to the procedure described by Pedrero and Pangborn (1997). To assess the perception of lactic acid taste in samples a non-structured scale of $10 \mathrm{~cm}$ with a minimum and a maximum ("without taste of lactic acid", and "with taste of lactic acid", respectively), was used. The sensory evaluation was carried out in 2 sessions, each session included 4 experiments (a control and three treated samples) according with an incomplete blocks experiment design. The order of sample presentation was balanced according to the procedure proposed by Macfie et al. (1989).

The overall acceptance of samples was determined with a 30 untrained judges panel (15 men and 15 women, 18-30 years old) using a nine point hedonic scale with $1=$ "dislike extremely", in the middle with "neither like nor dislike" and 9= "like extremely".

\section{Statistical Analysis}

Analysis of variance (ANOVA) was performed with a significance level of $5 \%$ with Modde 7.0 (Umetric $A B$ ) statistical package. The values of the response variables were taken as the change before and after treatment (between 0 and 7 days), excepting hardness, that was carried out just at the end of storage stage. The multiple regression method (MLR) (equation 3 ) was used to evaluate the main effects of the independent variables on each of the response variables:

$Y=b_{0}+b_{1} t+b_{2} C+b_{3} t * C+e$

where $Y$ is the response variable $(\mathrm{pH}$, color, hardness, weight loss in raw and cooked meat), $\mathrm{t}$ is the immersion time ( 1 and 3 minutes), $\mathrm{C}$ is the lactic acid concentration ( 1 and $3 \%$ ), $e$ is the residual error and $b_{0}, b_{1}, b_{2}, b_{3}$ represent the regression coefficients of the model.

The experimental values regarding taste were also analyzed through analysis of variance (ANOVA) with a significance level of $5 \%$ where the minimum significant difference was carried out by applying a Tuckey test, and using Minitab 14 software.

\section{Results and discussion}

\section{$\mathrm{pH}$}

Statistical analysis demonstrated that treatment with lactic acid did not cause any significant effect $(p>0.05)$ on $\mathrm{pH}$ of samples after 7 days of storage (Table 2). The pHu values ranged between 5.78 and 6.11 . However, after the treatment these values decline due to the effect of the concentration and time of immersion (Table 3). The development of $\mathrm{pH}$ (prior, during, and after treatment at 7 days of storage), for the 3 concentrations and maximum time of immersion ( 3 minutes) is shown in Table 3. It suggests that the pHu value has great influence on the $\mathrm{pH}$ value after treatment, as observed for the $2 \%$ concentration of lactic acid, where values of $\mathrm{pH}$ before and after treatment were $5.78 \pm 0.05$ and $4.43 \pm 0.14$, respectively, which were lower than treatment at 1 minute and $3 \%$. This decrease in $\mathrm{pH}$ after treatment is in according with 


\section{AGRICULTURAL AND FOOD SCIENCE}

A. Grajales-Lagunes et al. (2012) 21: 171-181

Medynski et al. (2000) who found pH values of 3.90 using lactic acid solutions of $1.5 \%$, in minced pork. In our results, it can be observed that at any concentration of lactic acid, $\mathrm{pH}$ increased after one day of storage and there were no significant changes in the next days of store stage. Jensen et al. (2003), reported values of $\mathrm{pH}$ between 5.70 and 5.94 after equilibrium using lactate and acetate salts to increase the shelf life of pork loin. Similar results have been reported by Naveena et al. (2006), using lactic acid to extend the shelf life of buffalo meat. The increase in $\mathrm{pH}$ observed during storage, may be due to proteolysis, which occurs during the ageing process, generating a certain content of free amino acids and dipeptides; these dipeptides may vary according with specie (Plowman and Close 1988). In addition, it may also due to buffering capacity meat at certain $\mathrm{pH}$ values (Goli et al. 2007).

Table 2. ANOVA results and $\mathrm{R}^{2}$, to evaluate the effect of lactic acid, immersion time and interaction, on meat quality properties.

\begin{tabular}{|c|c|c|c|c|c|}
\hline ANOVA & $\mathrm{pH}$ & Color change & $\begin{array}{l}\text { Hardness (N } \\
\left.\mathrm{cm}^{-2}\right)\end{array}$ & $\begin{array}{l}\text { Weight loss } \\
(\%) \text { raw meat }\end{array}$ & $\begin{array}{l}\text { Cooking loss } \\
(\%)\end{array}$ \\
\hline Model & 0.712 & 0.502 & 0.0001 & 0.0024 & 0.0530 \\
\hline Concentration $(\mathrm{C})$ & 0.643 & 0.149 & 0.0001 & 0.0005 & 0.0316 \\
\hline Immersion time $(\mathrm{t})$ & 0.516 & 0.965 & 0.0001 & 0.1040 & 0.0730 \\
\hline $\mathrm{C}^{*} \mathrm{t}$ Interaction & 0.419 & 0.836 & 0.0001 & 0.4260 & 0.4108 \\
\hline $\mathrm{R}^{2}$ & 0.135 & 0.22 & 0.999 & 0.7840 & 0.557 \\
\hline
\end{tabular}

Table 3. Mean values and standard deviations of $\mathrm{pH}$, for treatment of 3 minutes immersion time, before and during seven days storage.

\begin{tabular}{|c|c|c|c|c|c|c|c|c|c|}
\hline Con- & B e fore & $\mathrm{A} \mathrm{ft}$ e $\mathrm{r}$ & Days of sto & & & & & & \\
\hline $\begin{array}{l}\mathrm{tra}- \\
\text { tion } \\
(\%)\end{array}$ & $(\mathrm{pHu})$ & & 1 & 2 & 3 & 4 & 5 & 6 & 7 \\
\hline 1 & $6.11 \pm 0.08$ & $4.96 \pm 0.27$ & $5.92 \pm 0.11$ & $5.93 \pm 0.08$ & $6.05 \pm 0.11$ & $5.74 \pm 0.07$ & $5.78 \pm 0.05$ & $5.86 \pm 0.05$ & $5.89 \pm 0.07$ \\
\hline 2 & $5.78 \pm 0.05$ & $4.43 \pm 0.14$ & $5.49 \pm 0.08$ & $5.71 \pm 0.11$ & $5.42 \pm 0.02$ & $5.44 \pm 0.06$ & $5.52 \pm 0.02$ & $5.55 \pm 0.04$ & $5.59 \pm 0.13$ \\
\hline 3 & $5.99 \pm 0.09$ & $4.88 \pm 0.46$ & $5.60 \pm 0.10$ & $5.63 \pm 0.08$ & $5.73 \pm 0.10$ & $5.72 \pm 0.10$ & $5.73 \pm 0.09$ & $5.73 \pm 0.08$ & $5.71 \pm 0.06$ \\
\hline
\end{tabular}




\section{AGRICULTURAL AND FOOD SCIENCE}

A. Grajales-Lagunes et al. (2012) 21: 171-181

\section{Color change}

Color change was not affected ( $p>0.05$ ) by any factors assessed (lactic acid concentration and time of treatment) (Table 2). The average value of color change ( $\Delta \mathrm{E})$ between 0 and 7 days for samples treated at $1 \%$ for one minute, and control, were $3.64 \pm 0.55$ and $3.53 \pm 0.33$, respectively. Values obtained for samples treated at $2 \%$ for 2 minutes and control, were $4.37 \pm 1.47$ and $4.30 \pm 1.45$, respectively. The value of $\Delta \mathrm{E}$ for treatment at $3 \%$, during 3 minutes was $3.70 \pm 0.05$, and $4.30 \pm 0.07$ for control. Values of $\Delta E$ for other treatment times were similar to values previously presented. Figure 1 shows the results of the Hue value regarding all the experiments with their respective replicate at different days of storage. These results indicate that Hue value remains constant in control sample, as well as for the samples treated. The Hue value for treated samples at 7 days was between 50 and 55 . Is important to indicate that there was a slight variation in color parameters $L^{*}(42.26-48.46), a^{*}(7.84-10.77)$ and $b^{*}(10.15-15.58)$ in all trials during storage. Color changes observed in this work may be due mainly to a decrease in oxygen (vacuum packed samples) because increase in $\mathrm{pH}$ was not significant during the 7 days of storage. Results of this work indicate that lactic acid does not have a negative influence on meat color, which is in concurrence with those observed by Pipek et al. (2005), studying the effect of steam and lactic acid in beef and pork carcasses. Unfortunately, in the available literature, it was difficult to find detailed results of the color parameters in pork in similar conditions. However, these results could be the basis for future studies related to use the lactic acid to increase the shelf life of pork.

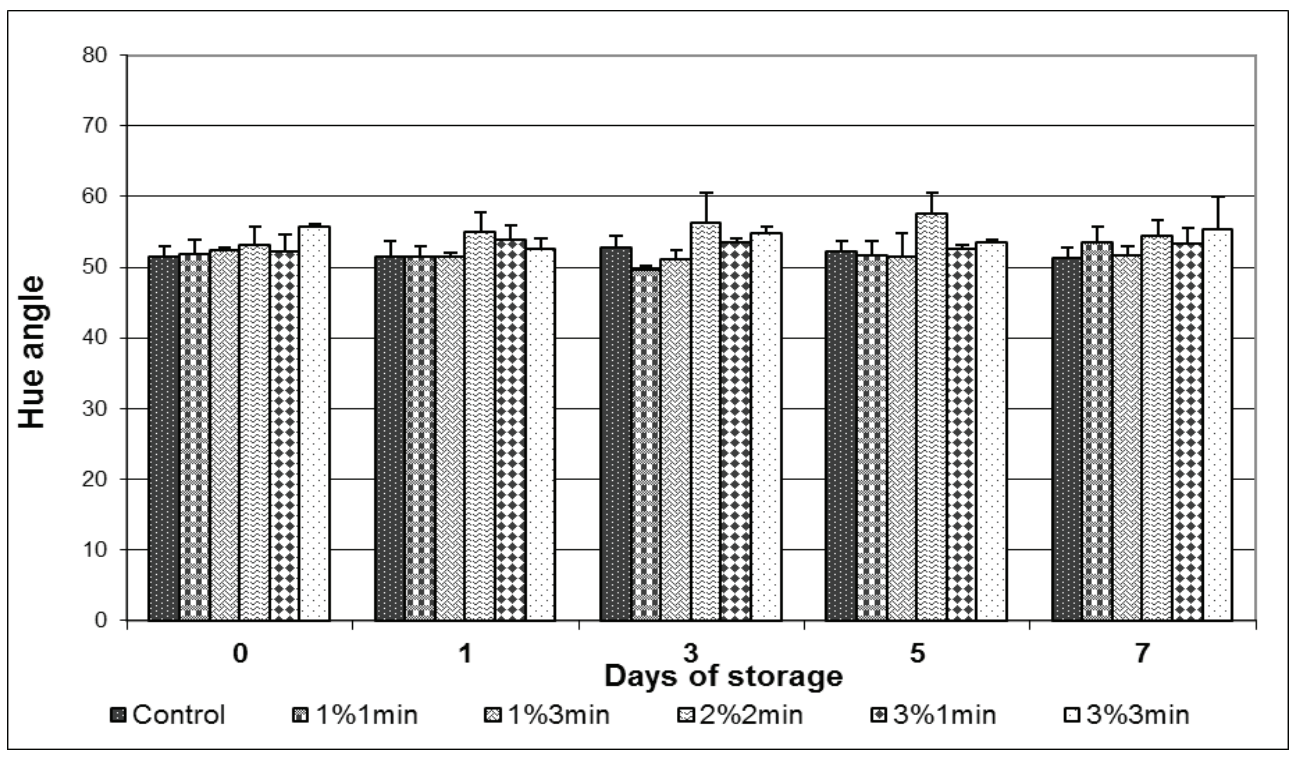

Fig. 1. Hue angle on raw meat during 7 days of storage for all treatments.

\section{Meat texture}

The statistical analysis (Table 2) indicates that lactic acid concentration and immersion time and their interaction caused significant effect on hardness $(p<0.05)$. The following statistical mode was obtained: 


\section{AGRICULTURAL AND FOOD SCIENCE}

A. Grajales-Lagunes et al. (2012) 21: 171-181

$(A+5.48)=\left(4.42-1.47 * C-1.46 * t+0.50 * C^{*} t\right)^{-1}$

where $\mathrm{A}$ is meat hardness, $\mathrm{C}$, lactic acid concentration, and $\mathrm{t}$ immersion time.

According to the equation (4), an increase in the concentration of lactic acid indicates a reduction in meat hardness. The resistance of meat decreased with the increasing lactic acid during 7 days storage (Fig. 2). Previous studies have already shown the positive effect of injecting lactic acid on beef texture (Ertbjerg et al. 1999; Berge et al. 2001). Berge et al. (2001) observed that injecting lactic acid accelerates meat tenderization, reducing hardness after two days post mortem in beef muscle (Pectoralis profundus) with a high content of collagen. The efficiency of acid treatment depends not only on the intrinsic toughness of the meat (Berge et al. 2001, Wenham and Locker 1976), but also on the type and the acid concentration, time and method of treatment (immersion, spray, injection). For example, Gault (1985) examined the effects of low $\mathrm{pH}$, obtained by the addition of acetic acid solutions, on cooked meat tenderness. Peak force was maximum at $\mathrm{pH}$ values around 5.0 (range 4.5-5.5) and decreased sharply as the $\mathrm{pH}$ decreased from 4.6 to values lower than 4.1. However, with $\mathrm{pH}$ values obtained in this study $(5.59 \pm 0.13-5.89 \pm 0.07)$ also showed a reduction in hardness, suggesting that at $\mathrm{pH}$ below or above of isoelectric point of myofibrillar proteins (around 5), hardness decrease. These results agree with those reported by Sheard and Tali (2004). According with Berge et al. (2001), the mechanism of meat tenderization by lactic acid could be a weakening of the myofibrillar structure resulting in the rupture of M-lines and I-bands of sarcomere, as well as the acceleration of the release of the lysosomal proteases and the higher activity of cathepsins $\mathrm{B}+\mathrm{L}$ in the soluble fraction.

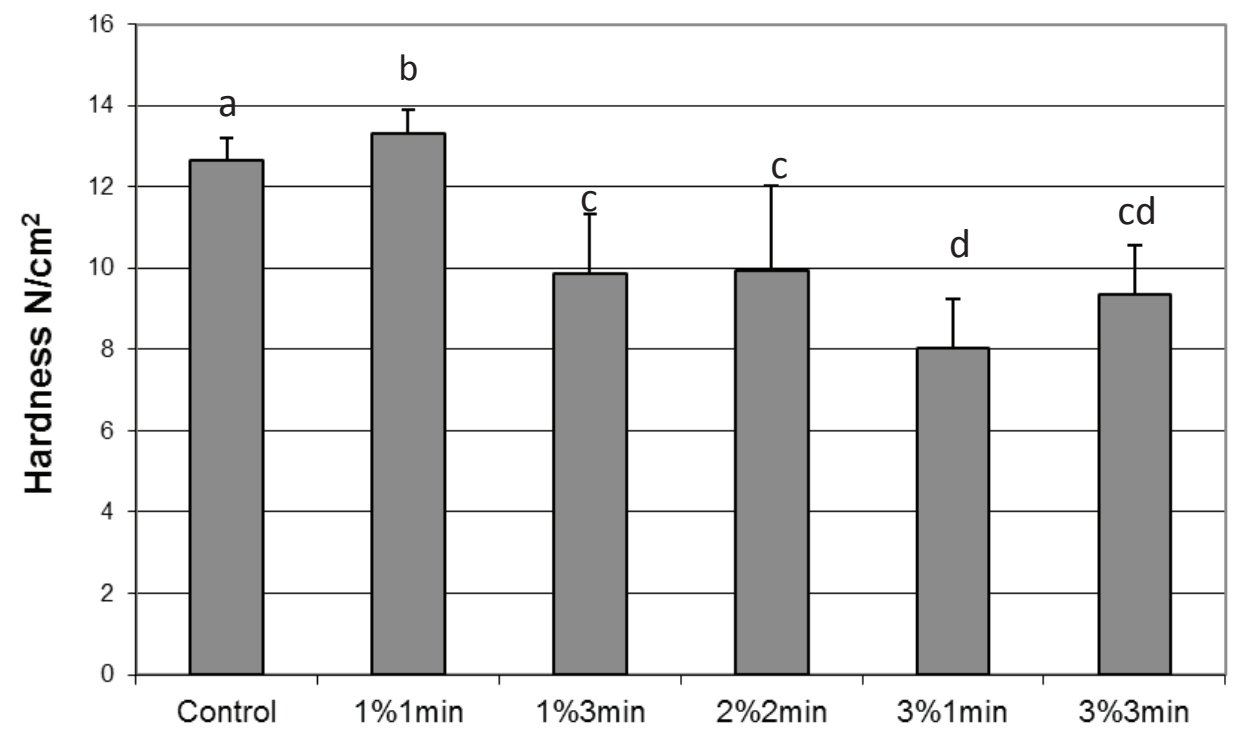

Fig. 2. Hardness of raw meat at 7 days of storage. Different letters between two columns indicate a statistically significant difference $(p<0.05)$. 


\section{AGRICULTURAL AND FOOD SCIENCE}

A. Grajales-Lagunes et al. (2012) 21: 171-181

\section{Weight loss in raw and cooked meat}

The statistical analysis of weight loss (Table 2 ) indicated that only lactic acid concentration caused a significant effect $(p<0.05)$ on this variable. The statistic model obtained was:

$\mathrm{WL}=-4.35+6.57 * \mathrm{C}+3.25 * \mathrm{t}-0.78 * \mathrm{C} * \mathrm{t}$

where $\mathrm{C}$ and $\mathrm{t}$ are lactic acid concentration and immersion time, respectively and $\mathrm{WL}$ is the weight loss (raw meat). The average results of weight loss in raw meat, for each experiment at 7 days of storage are presented in Figure 3. The lowest percentage of weight loss, about 4-5\%, was for the control and samples treated with $1 \%$ lactic acid at 1 minute, and the highest for samples treated with $3 \%$ at 1 and 3 minutes, about $18 \%$. Weight loss is related with $\mathrm{pH}$ value, because when the $\mathrm{pH}$ is near the isoelectric point of proteins, weight losses are greater, due to the change in water holding capacity. Medynski et al. (2000) found higher water holding capacity and lower weight losses in pork samples treated with $1.5 \%$ lactic acid, and pH of 3.9. This $\mathrm{pH}$ value is below the isoelectric point of proteins, where it has been demonstrated that the water holding capacity is higher (Rao and Gault 1989). This suggests that if the $\mathrm{pH}$ is lower or higher than 5, weight loss decreases (Hamm 1960), probably due to swelling that occur in myofibrillar proteins and connective tissue. The weight loss obtained in our study was probably due to the final acidity, as well as the type of muscle fiber (Rao et al. 1989), since there is more swelling in the white fibers than in the red ones, suggests a higher water holding capacity. The muscle analyzed in this study is composed predominantly of red fibers. Respect to cooking loss, the statistical analysis (Table 2) showed, that the concentration of lactic acid was the factor that caused effect on this variable $(p<0.05)$. The results of the averages from the cooking loss are shown in Figure 4 for each experiment at 7 days of storage. In general, it was observed that the control sample, and samples treated at $1 \%$ lactic acid, had weight loss of approximately $20 \%$, for samples treated at $2 \%$ and $3 \%$, weight loss were of $25 \%$ and $32 \%$, respectively. Our results agree with those obtained by Sheard and Tali (2004) injecting salt, tripolyphosphate and bicarbonate solutions and Jensen et al. (2003) , using lactate and acetate, both in pork; as well as with the results of Jiménez-Villareal et al. (2003a) using lactic acid in beef.

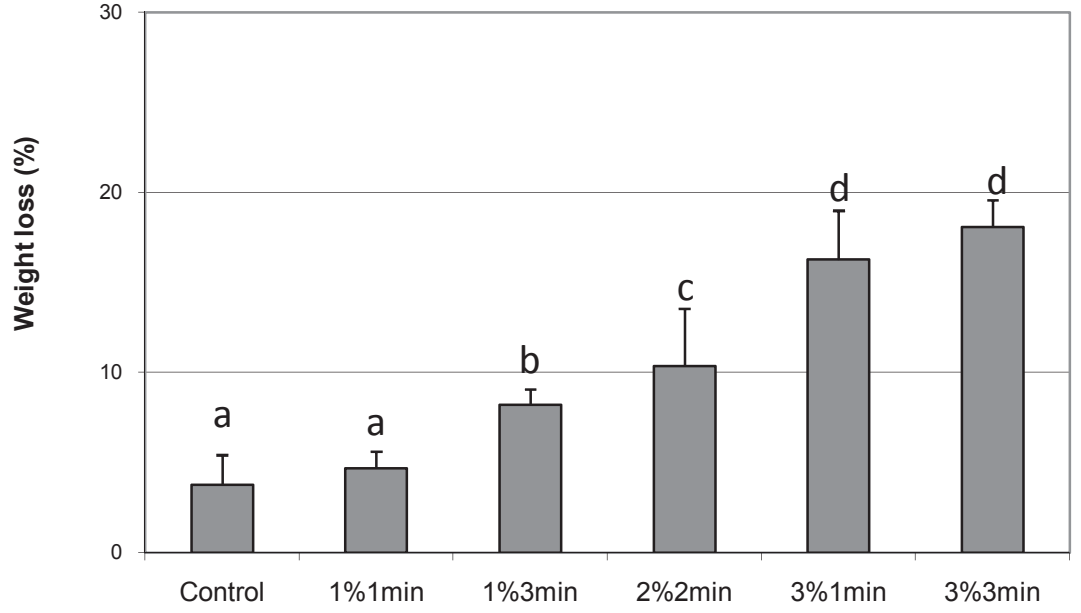

Fig. 3. Weight loss in raw meat at 7 days of storage. Different letters between two columns indicate a statistically significant difference $(p<0.05)$. 


\section{AGRICULTURAL AND FOOD SCIENCE}

A. Grajales-Lagunes et al. (2012) 21: 171-181

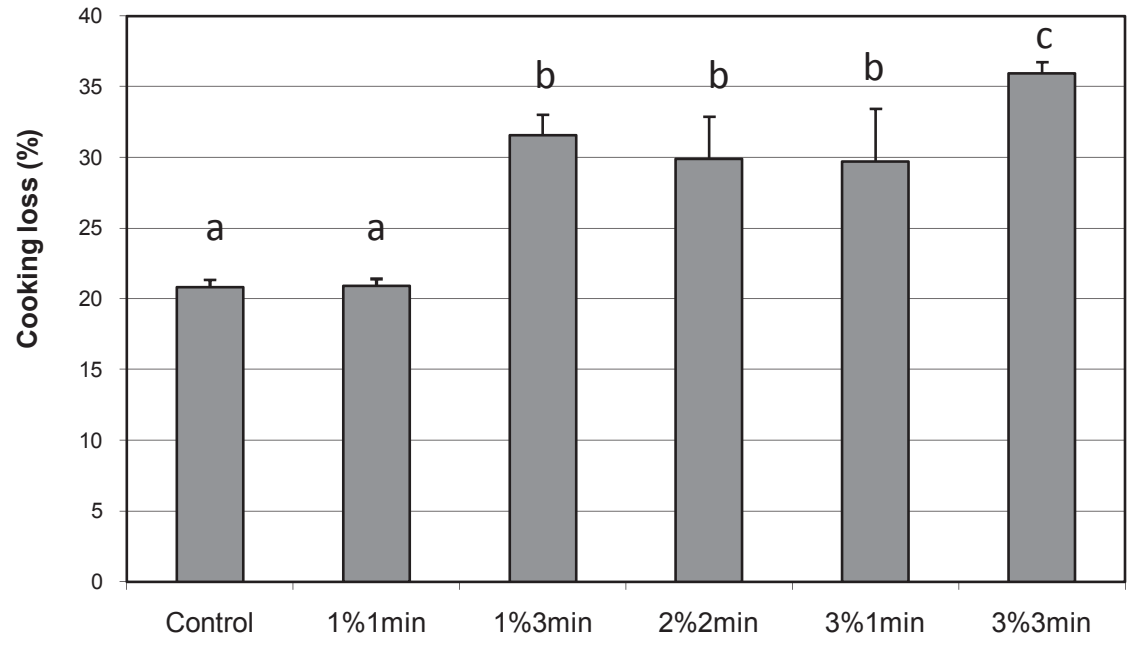

Fig. 4. Cooking loss at 7 days storage. Different letters between two columns indicate a statistically significant difference $(p$ $<0.05$ ).

\section{Taste evaluation}

Results provided by trained judges indicate that lactic acid taste is enhanced as concentration and time of immersion are increased (Table 4). They pointed out that lactic acid taste is not disagreeable, and the meat may be consumed without any problem regarding taste. Results obtained by untrained judges were "I like lightly" and "I like very much"; the sample with major acceptance was 3\% lactic acid, at 1 minute immersion. This indicates that for the untrained judges the lactic acid taste was agreeable too, because they emphasized that "the meat has a different taste, but it is delicious and tender".

Table 4. Means of lactic acid taste and overall acceptance scores of different treatments

\begin{tabular}{llll}
\hline $\begin{array}{l}\text { Samples } \\
\%\end{array}$ & minutes & Lactic acid taste $*$ & Overall acceptance** \\
\hline 0 & 0 (Control) & $1.3 \pm 0.80 \mathrm{a}$ & $6.4 \pm 0.36 \mathrm{a}$ \\
1 & 1 & $1.7 \pm 0.75^{\mathrm{a}}$ & $6.2 \pm 0.80^{\mathrm{a}}$ \\
2 & 3 & $4.2 \pm 0.55^{\mathrm{b}}$ & $6.3 \pm 1.00^{\mathrm{a}}$ \\
& 2 & $3.9 \pm 0.28^{\mathrm{b}}$ & $6.0 \pm 0.87^{\mathrm{a}}$ \\
3 & 1 & $4.0 \pm 0.78^{\mathrm{b}}$ & $7.9 \pm 0.53^{\mathrm{b}}$ \\
& 3 & $6.7 \pm 0.45^{\mathrm{c}}$ & $6.9 \pm 0.33^{\mathrm{c}}$ \\
\hline
\end{tabular}

* The score means were obtained by 8 trained judges.

** The score means were obtained by 30 untrained judges.

Means with the same letter in a column are not significantly different $(p>0.05)$. 


\section{AGRICULTURAL AND FOOD SCIENCE}

A. Grajales-Lagunes et al. (2012) 21: 171-181

\section{Conclusions}

The results of this study showed that color and $\mathrm{pH}$ of meat were not affected by lactic acid treatment. However lactic acid caused significant effect in hardness and weight loss. The percentage of weight loss, in raw and cooked meat, was within the range reported by other authors, where a great reduction of toughness of meat can be observed. Based on sensory analysis scores, of trained and untrained judges, lactic acid did not caused any significant effect on the taste of pork, so this method (immersion in lactic acid) can be used to extend its shelf life.

\section{Acknowledgements}

This research was carried out with the financial supports of FAI-UASLP (Project C06-FAI-11-20.57) and Ximonco S.A. de C.V., company.

\section{References}

Anzaldúa-Morales, A. 1994. Los jueces y las condiciones de prueba. In: Acribia, S.A. (ed). La Evaluación Sensorial de los Alimentos en la teoría y la práctica. Zaragoza España. p. 45-65.

Berge, P., Ertbjerg, P., Melchior, L.L., Astruc. T., Vignon, X. \& Muller, A.J. 2001. Tenderization of beef by lactic acid injected at different times post mortem. Meat Science 57: 347-357.

Booth, I.R. 1985. Regulation of cytoplasmic pH in bacteria. Microbiology Reviews 49: 359-378.

Castillo, A., Lucia, L.M., Mercado, I. \& Acuff, G.R. 2001. In plant evaluation of a lactic acid treatment for reduction of bacterial on chilled beef carcasses. Journal of Food Protection 64: 738-740.

Deumier, F. 2004. Pulsed vacuum immersion of chicken meat and skin in acid solutions. Effects on mass transfers, colour and microbial quality. International Journal Food Science and Technology. 39: 277-286.

Dorsa, W.J., Cutter, C.N., Siragusa, G.R. \& Koohmaraie, M. 1996. Microbial decontamination of beef and sheep carcasses by steam, hot water washes, and steam-vacuum sanitizer. Journal of Food Protection 59: 127-135.

Ertbjerg, P., Mielche, M.M., Larsen, L.M. \& Mùller, A.J. 1999. Relationship between proteolytic changes and tenderness in prerigor lactic acid marinated beef. Journal of the Science of Food and Agriculture 79: 970-978.

Gault, N.F.S. 1985. The relationship between water-holding capacity and cooked meat tenderness in some beef muscles as influenced by acidic conditions below the ultimate $\mathrm{pH}$. Meat Science 15: 15-30.

Goli, T., Nakhoul , A.P., Zakhia, R.N, Trystram, G. \& Bohuon, P. 2007. Chemical equilibrium of minced turkey meat in organic acid solutions. Meat Science 75: 308-314.

Ozdemir, H., Yildirm, Y., Kuplulu, O., Koluman, A., Goncuoglu, M. \& Inat, G. 2006. Effects of lactic acid and hot water treatments on Salmonella Typhimurium and Listeria monocytogenes on beef. Food Control 17: 299-303.

Hamm, R. 1960. Biochemistry of meat hydration. Advances in Food Research 10: 355-463.

Hunt, M.C., Acton, J.C., Benedict, R.C., Calkins, C.R., Cornforth, D.P., Jeremiah, L.E., Olson, D.G., Salm, C.P., Savell, J.W. \& Shivas, S.D. 1991. AMSA guidelines for meat color evaluation, Proceedings 44th Annual Reciprocal Meat 9-12 July, Kansas State University, Manhattan, KS.

Ikeda, J.S., Samelis, J., Kendall, P.A., Smith, G.C. \& Sofos, J.N. 2003. Acid adaptation does not promote survival or growth of Listeria monocytogenes on fresh beef following acid and nonacid decontamination treatments. Journal of Food Protection 66: 985-992.

Jensen, J.M., Robbins, K.L., Ryan, K.J., Homco, R.C., Mckeith, F.K. \& Brewera, M.S. 2003. Effects of lactic and acetic acid salts on quality characteristics of enhanced pork during retail display. Meat Science 63: 501-508.

Jimenez Villarreal, J.R., PohIman, F.W., Johnson, Z.B. \& Brown, A.H. 2003a. Lipid, instrumental color and sensory characteristics of ground beef produced using trisodium phosphate, cetylpypiridium chloride, chloride dioxide or lactic acid as multiple antimicrobial interventions. Meat Science 65: 885-891. 


\section{AGRICULTURAL AND FOOD SCIENCE}

A. Grajales-Lagunes et al. (2012) 21: 171-181

Jimenez Villarreal, J.R., PohIman, F.W., Johnson, Z.B. \& Brown, A.H. 2003b. Effects of dioxide, cetylpyridinium chloride, lactic acid and trisodium phosphate on physical, chemical and sensory properties of ground beef. Meat Science 65: 1055-1062.

Kotula, K.L. \& Thelappurath, R. 1994. Microbiological and sensory attributes of retail cuts of beef treated with acetic and lactic acid solutions. Journal of Food Protection 57: 665-670.

Kozempel, M., Goldberg, N. \& Craig, J.C. 2003. The vacuum/steam/vacuum process. Food Technolology 57: 30-33.

Lawrie, R.A. 1998. Estructura y crecimiento del músculo. In: Lawrie, R.A. (ed.). Ciencia de la carne. Zaragoza España: Acribia S.A. p. 35-64.

Lepetit, J. \& Buffiere, C. 1993. Comparaison de deux méthodes mécaniques de mesure de la résistance myofibrillaire de la viande crue. Viandes Produits Carnés 14: 39-42.

Macfie, H.J., Bratchell, N., Greenhoff, H. \& Vallis, L.V. 1989. Designs to balance the effect of order of presentation and first-order carry-over effects in hall test. Journal of Sensory Studies 4: 129-149.

Medynski, A., Pospiech, E. \& Kniat, R. 2000. Effect of concentrations of lactic acid and sodium chloride on selected physico-chemical meat traits. Meat Science 55: 285-290.

Naavena, B.M., Muthukumar, M., Sen, A.R., Babji, Y. \& Murthy, T.R.K. 2006. Improvement of shelf-life of buffalo meat using lactic acid, clove oil and vitamin C during retail display. Meat Science 74: 409-415.

Pedrero, D.L. \& Pangborn, R.M. 1997. Análisis Secuencial. In: Alhambra Mexicana, S.A. (ed). Evaluación Sensorial de Alimentos. México D.F. p. 117-121.

Pipek, P., Houska, M., Jelenikova, J., Kyhos, K., Hoke, K. \& Sikulová, M. 2005. Microbial decontamination of beef carcasses by combination of steaming and lactic acid spray. Journal of Food Engineering 67: 309-315.

Plowman, J.E. \& Close, E.A. 1988. An evaluation of a method to differentiate the species of origin of meats on the basis of the contents of anserine, balenine and carnosine in skeletal muscle. Journal of the Science of Food and Agriculture 45: 69-78.

Rao, M. \& Gault, N.F.S. 1989. The influence of fibre-type composition and associated biochemical characteristics on the acid buffering capacities of several beef muscles. Meat Science 26: 5-18.

Rao, M. V., Gault, N. F. S. \& Kennedy, S. 1989. Variations in water-holding capacity due to changes in the fibre diameter, sarco-mere length and connective tissue morphology of some beef muscles under acidic conditions below the ultimate $\mathrm{pH}$. Meat Science, 26:19-37.

Rodriguez Hernandez, G.R., Gonzalez Garcia R., Grajales Lagunes A., Ruiz Cabrera M.A. \& Abud Archila M. 2005. Spray-Drying of Cactus Pear Juice (Opuntia streptacantha): Effect on the Physicochemical Properties of Powder and Reconstituted Product. Drying Technology 23: 965-973.

Sheard, P.R. \& Tali, A. 2004. Injection of salt, tripolyphosphate and bicarbonate marinade solutions to improve the yield and tenderness of cooked pork loin. Meat Science 68: 305-311.

Surve, A.N., Sherikar, A.T., Bhilegaonkar, K.N. \& Karakare, U.D. 1991. Preservative effect of combination of acetic acid with lactic or propionic acid on buffalo meat stored at refrigeration temperature. Meat Science 29: 309-322.

Tamblyn, K.C. \& Conner, D.E. 1997. Bactericidal activity of organic acids against Salmonella typhimurium attached to broiler chicken skin. Journal of Food Protection 60: 629-633.

Van Netten, P., Mossel, D. \& Huis In't Veld, J.H.J. 1995. Lactic acid decontamination of fresh pork carcasses a pilot plant study. International Journal of Food Microbiology 25: 1-9.

Van Netten, P., Valentijn, A., Mossel, D.A.A. \& Huis In't Veld, J.H.J. 1998. The survival and growth of acid-adapted mesophilic pathogens that contaminate meat after lactic acid decontamination. Journal Applied Microbiology 84: $559-567$.

Wenham, L.M. \& Locker, R.H. 1976. The efect of marinading on beef. Journal of the Science of Food and Agriculture 27: 1079-1084. 